\title{
Impacts of Biochar on Physical Properties and Erosion Potential of a Mudstone Slopeland Soil
}

\author{
Zeng-Yei Hseu, ${ }^{1}$ Shih-Hao Jien, ${ }^{2}$ Wei-Hsin Chien, ${ }^{2}$ and Ruei-Cheng Liou ${ }^{2}$ \\ ${ }^{1}$ Department of Environmental Science and Engineering, National Pingtung University of Science and Technology, \\ Pingtung 91201, Taiwan \\ ${ }^{2}$ Department of Soil and Water Conservation, National Pingtung University of Science and Technology, Pingtung 91201, Taiwan
}

Correspondence should be addressed to Shih-Hao Jien; shjien@mail.npust.edu.tw

Received 25 August 2014; Accepted 18 November 2014; Published 8 December 2014

Academic Editor: Manuel Tejada

Copyright (C) 2014 Zeng-Yei Hseu et al. This is an open access article distributed under the Creative Commons Attribution License, which permits unrestricted use, distribution, and reproduction in any medium, provided the original work is properly cited.

\begin{abstract}
Food demand and soil sustainability have become urgent issues recently because of the global climate changes. This study aims to evaluate the application of a biochar produced by rice hull, on changes of physiochemical characteristics and erosion potential of a degraded slopeland soil. Rice hull biochar pyrolized at $400^{\circ} \mathrm{C}$ was incorporated into the soil at rates of $2.5 \%, 5 \%$, and $10 \%$ (w/w) and was incubated for $168 \mathrm{~d}$ in this study. The results indicated that biochar application reduced the Bd by $12 \%$ to $25 \%$ and the PR by $57 \%$ to $92 \%$ after incubation, compared with the control. Besides, porosity and aggregate size increased by $16 \%$ to $22 \%$ and by 0.59 to $0.94 \mathrm{~mm}$, respectively. The results presented that available water contents significantly increased in the amended soils by $18 \%$ to $89 \%$ because of the obvious increase of micropores. The water conductivity of the biochar-amended soils was only found in $10 \%$ biochar treatment, which might result from significant increase of macropores and reduction of soil strength (Bd and PR). During a simulated rainfall event, soil loss contents significantly decreased by $35 \%$ to $90 \%$ in the biochar-amended soils. In conclusion, biochar application could availably raise soil quality and physical properties for tilth increasing in the degraded mudstone soil.
\end{abstract}

\section{Introduction}

The problems of food requirement and land resource have become urgent issues in the recent several decades due to climate changes. Additionally, soil degradation, such as erosion, hardsetting, and desertification, poses a serious problem affecting the productivity of agricultural lands and also threatens the world's food security in the future with increasing global population [1-4]. Development of new land management techniques to effectively use soil resources and attend land sustainability is necessary in the future, particularly in subtropical/tropical regions. Biochar has attracted attention for remediation of degraded soils recently, which is a byproduct derived from a process in which biofuel is produced using anaerobic pyrolysis at high temperatures. Biochar has been considered a suitable organic amendment for improving the physical properties and maintaining the fertility of soil, particularly degraded soils in subtropical and tropical regions [5-8].
Numerous studies have indicated that biochar effectively improves soil structure $[9,10]$, soil aggregate stability $[11-$ 15], and porosity [16] because of its high specific surface area (SSA) and inner porous structure. Steiner et al. [17], Chan et al. [6], Laird et al. [18], and Yuan and Xu [19] have reported that fertilizer-use efficiency and crop production increase following biochar incorporation. Biochar is composed of recalcitrant carbon from microbial degradation and of a charged surface with organic functional groups; therefore, it can increase soil organic carbon (SOC) levels and C stocks [20-23]. Biochar application could produce agronomic benefits, particularly fertility maintenance, SOC sequestration, and crop production $[5,8,24-26]$. However, few studies have examined the benefits of biochar application on the hydraulic properties and erosion recalcitrant of soil.

Hardsetting mudstone soils are considered a degradation soil because the soils are difficult to cultivate until the soil profile is rewetted [27] and they exhibit very high erosion potential. Mullins et al. [28] explained that hardsetting soils 
set to a hard, structureless mass during drying. Hardsetting mudstone soils constitute the area of over $1000 \mathrm{~km}^{2}$ of land in Taiwan [29]. Chen [30] reported that approximately 8 to $10 \mathrm{~cm}$ of soil is eroded from the surfaces of mudstone landscapes yearly, corresponding to a soil loss rate of $160 \mathrm{Mg} \mathrm{ha}^{-1}$ per year in Taiwan.

Natural organic materials (e.g., green manure) and artificial polymers (e.g., polyacrylamides) have been used to ameliorate degraded soils $[31,32]$. However, maintaining the long-term aggregate stability of soil by applying fresh organic residues is difficult because of the rapid degradation of these traditional amendments. In addition, polymer application is costly because polymers are expensive [31]. In Taiwan, techniques such as retaining walls and shotcretes are commonly used to protect soil from erosion in mudstone areas; however, these techniques are ineffective in situ. Hence, biochar may be a potential amendment that could protect hardsetting soil from rapid degradation in the long term, thus increasing the value of Taiwanese agronomy and engineering. Few published studies have focused on the influence of biochar on the hydraulic properties and erodibility of soil. The purposes of this study were to (1) explore the effects of biochar on the physical and hydraulic properties and erosion potential of the mudstone soil and (2) assess the relationship between the physical properties and erosion potential of the soil.

\section{Materials and Methods}

2.1. Soil and Biochar Collection. Mudstone occupied over than $1000 \mathrm{~km}^{2}$ in Taiwan [29] (Figure 1(a)). Outcrops of the mudstone formation were only found in southwestern Taiwan and occupied about 3\% of land area of Taiwan. The mudstone formation formed from marine sediments from the littoral zone during the Miocene to Pliocene and Pleistocene Epochs. Sedimentary rocks created during the late Miocene Epoch to the Pleistocene Epoch can be several thousand meters deep. The geological stratigraphy is rather monotonic, consisting mainly of massive mudstones or alternating between mudstone and sandstone. In southern Taiwan, most of the mudstone slopeland soils with slope gradient below $20^{\circ}$ are used for crop production. However, poor soil qualities, such as hardsetting, crusting, and erosion, often occur in these mudstone slopelands and result in poor production. Moreover, mudstone landscapes are characterized by sparse vegetation and can be subjected to erosion during the rainfall season from May to October in Taiwan. The soil sample for this study was collected from the surface $(0-25 \mathrm{~cm})$ of a mudstone site in the Tianliao area (E $120^{\circ} 22^{\prime} 58^{\prime \prime}$, N $22^{\circ} 53^{\prime} 02^{\prime \prime}$ ), Kaohsiung, Taiwan (Figure 1(b)). These mudstone soils could be classified as Typic Eutrustept according to the U.S. Soil Taxonomy [33].

The biochar used in this study was produced from rice hulls and supplied by the Industrial Technology Research Institute (ITRI) of Taiwan. Before charring, the rice hull was dried at $60^{\circ} \mathrm{C}$ for $24 \mathrm{~h}$ to $<10 \%$ moisture and cut to a particle size of $2 \mathrm{~cm}$. For pyrolysis, the samples were placed in a tubular furnace (ITRI, Tainan, Taiwan) equipped with a corundum tube $(32 \mathrm{~mm}$ in diameter and $700 \mathrm{~mm}$ in length) with a $\mathrm{N}_{2}$ purge $(1 \mathrm{~L} / \mathrm{min}$ flow rate) to ensure an oxygen-free atmosphere. Heat treatments were performed in the temperature of $400^{\circ} \mathrm{C}$. The heating rate was $5^{\circ} \mathrm{C} \mathrm{min}{ }^{-1}$. Temperature was maintained for $2 \mathrm{hrs}$ before cooling to ambient temperature under $\mathrm{N}_{2}$ flow. The produced rice hull biochar was denoted as RHB-400 later in this study. After pyrolysis, the biochar was ground to enable it to pass through a $2 \mathrm{~mm}$ sieve, ensuring that all the biochar used in the experiments exhibited similar particle sizes. Rice hulls are considered agricultural waste, and they generate at least one million tons of waste per year in Taiwan. Recycling this waste and using it as an amendment for soil is favorable.

2.2. Analyses of Soil and Biochars. The soil samples were airdried and ground to pass through a $2 \mathrm{~mm}$ sieve for subsequent analysis. The particle size distribution was determined using the pipette method [34]. The soil $\mathrm{pH}$ was determined using a $1: 2.5$ ratio of soil to water [35]. The content of carbon and nitrogen in the soil was measured using a Fisons NA1500 elemental analyzer (Thermo Electron Corporation, Wattham, Massachusetts, USA). The soil organic carbon content was determined using the wet oxidation method [36]. The cation exchange capacity (CEC) and exchangeable bases were measured using the ammonium acetate $(\mathrm{pH}=7)$ method [37]. The calcium carbonate contents were determined by simple titrimetric method [38], where finely ground soil and biochar samples $(2.0 \mathrm{~g})$ were reacted with $2 \mathrm{M} \mathrm{HCl}$ for $16 \mathrm{~h}$. The emitted $\mathrm{CO}_{2}$ in the reacted bottle was captured by $\mathrm{NaOH}$ and then was titrated by $0.1 \mathrm{M} \mathrm{HCl}$, where titrated $\mathrm{HCl}$ volume was used to calculate $\mathrm{CaCO}_{3}$ contents. The bulk density (Bd) was determined using the core method [39], in which a stainless steel core ( $5 \mathrm{~cm}$ in diameter and $10 \mathrm{~cm}$ in height) was used to collect soil core to determine soil Bd in each sampling time during incubation. The saturated hydraulic conductivity $\left(K_{\text {sat }}\right)$ was determined by applying the constant head method [40]. The $K_{\text {sat }}$ was measured in saturated soil packed in a core (the same core as with the determination of $\mathrm{Bd}$ ). Water was added to the extended soil cores and a constant head was maintained until the effluence flow was reasonably steady. Then water depths inside and outside the cores were recorded; meanwhile, the effluent water volume was also recorded in a given time, and then $K_{\text {sat }}$ was calculated based on Darcy's equation. Soil penetration resistance (PR) was measured by using a portable hardness tester (Soil Hardness Meter, Yamanaka type, Daiki Rika Kogyo Co., Japan). Modified fast wetting in water, as proposed by [41], was used to measure the aggregate stability of $2 \mathrm{~mm}$ air-dried aggregates $(35 \mathrm{~g})$. A $4 \mathrm{~cm}$ amplitude was applied to a nest of sieves (>2000 mm, 1000$2000 \mathrm{~mm}, 500-1000 \mathrm{~mm}, 250-500 \mathrm{~mm}, 250-106 \mathrm{~mm}$, and $<106 \mathrm{~mm})$ immersed in a container of tap water $(101 \mathrm{mS} / \mathrm{cm})$ during the $5 \mathrm{~min}$ of vertical movement. The material that remained in each sieve after wet shaking was carefully removed, and the mean weight diameter (MWD) of the aggregate size was calculated as follows:

$$
\mathrm{MWD}=\sum_{i=1}^{n} x_{i} w_{i}
$$




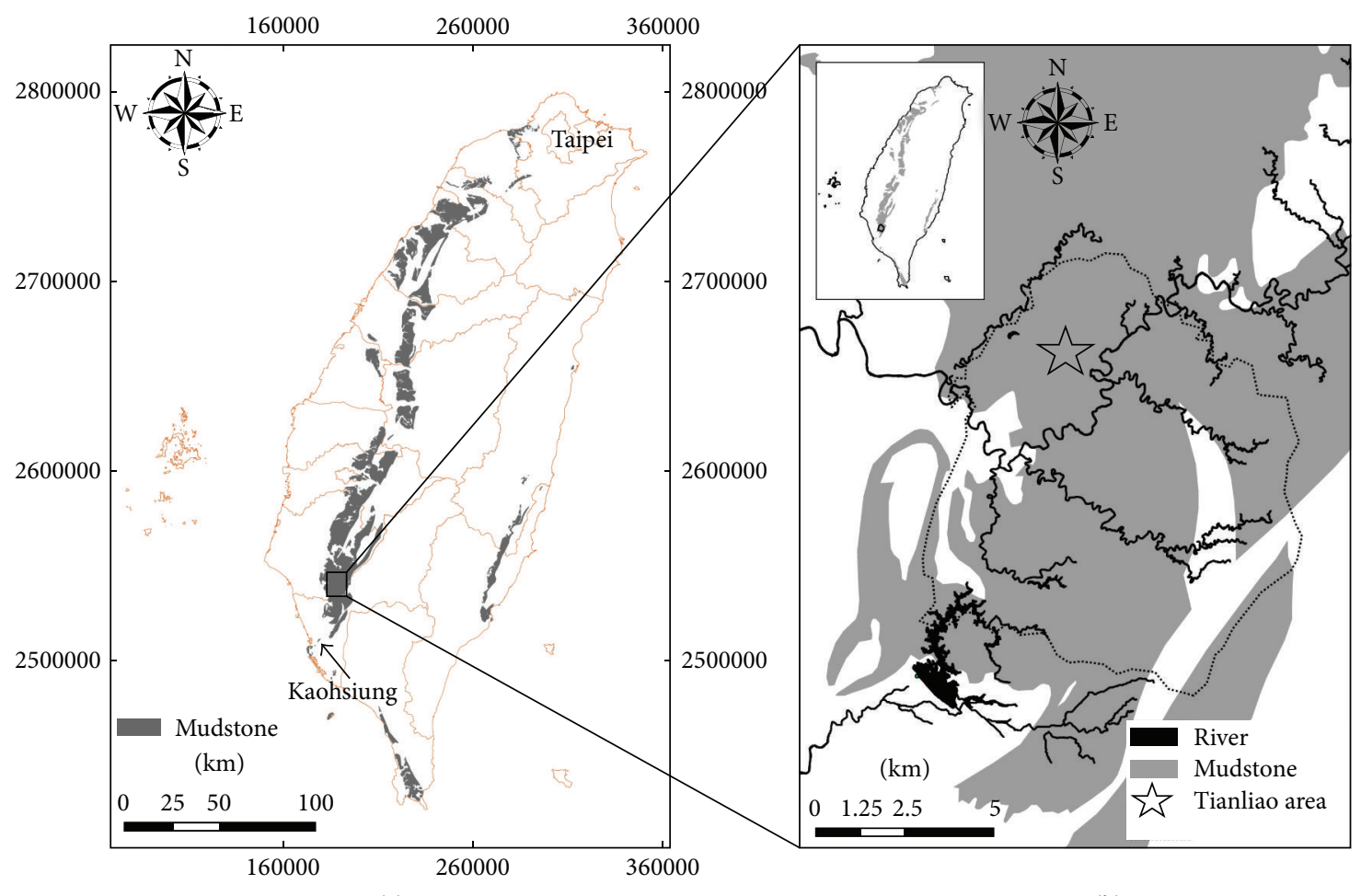

(a)

(b)

FIGURE 1: Location of soil sampling.

where $n$ is the number of sieves, $x$ is the diameter, and $w$ is the weight.

The SSAs of the soil and biochar were determined based on $\mathrm{N}$ adsorption isotherms at $77.3 \mathrm{~K}$ by using the BrunauerEmmett-Teller (BET) equation [42] (PMI Automated BET Sorptometer BET-202A). The microbial biomass carbon (MBC) content in the soil was determined using fumigation and extraction $[43,44]$. Fourier-transform infrared (FTIR) analysis was performed to test the quality of the biochar. Ground biochar (0.3-0.5 mg) was embedded in potassium bromide (KBr) pellets (99.5-99.7 mg) and measured using an FTIR spectrometer (VECTOR 22, Bruker, USA) with a $4 \mathrm{~cm}^{-1}$ resolution and 100 scans between the 4000- and 400$\mathrm{cm}^{-1}$ wavenumbers [45]. To analyze $\mathrm{C}$ forms based on the FTIR spectra, we subtracted the background of the $\mathrm{KBr}$ window, automatically corrected the baseline and smoothed the spectra, identified the peaks, and normalized the spectra on a reduced portion of the wavenumbers $\left(4000-500 \mathrm{~cm}^{-1}\right)$.

The MBC was estimated only at the end of the incubation. Subsamples collected from the incubated treatments were fumigated with ethanol-free chloroform for $24 \mathrm{~h}$ at $25^{\circ} \mathrm{C}$. After chloroform removal, the subsample was extracted using a $200 \mathrm{~mL} 0.5 \mathrm{M} \mathrm{K}_{2} \mathrm{SO}_{4}$ solution for $30 \mathrm{~min}$. The organic carbon in the extract was measured by performing wet digestion using dichromate and titration using $\mathrm{FeSO}_{4}$.

Soil water retention curve was determined by a pressure plate method, in which a Buchner funnel with a ceramic plate connected with a burette by plastic tubing was used for this experiment. The measured soil water retention data at different matric potentials $(500 \mathrm{~cm}, 1,000 \mathrm{~cm}, 3,000 \mathrm{~cm}$,
$6,000 \mathrm{~cm}$, and $12,000 \mathrm{~cm}$ ) and the air-dry water content with an assumed suction of $15,000 \mathrm{~cm}$ were used to fit the soil water retention model [46]:

$$
\theta=\theta_{r}+\frac{\theta_{s}-\theta_{r}}{\left[1+(\alpha|h|)^{n}\right]^{1-1 / n}} .
$$

Here $\theta$ is volumetric soil water content (cubic centimeters per cubic centimeter), $h$ is the suction (centimeters), $\theta_{r}$ and $\theta_{s}$ are the residual water content and saturated water content (cubic centimeters per cubic centimeter), respectively, and $\alpha$ (per centimeter) and $n$ are the fitting parameters. The plant available water content was calculated by the difference between the field capacity (the water content at suction of $330 \mathrm{~cm}$ ) and the wilting point (the water content at suction of $15,000 \mathrm{~cm}$ ). According to the definition of macropores [47], which are the pores with diameters $>75 \mu \mathrm{m}$ (corresponding to $h>$ $-40 \mathrm{~cm}$ ), the amount of macropores (cubic centimeters per cubic centimeter) was derived from the soil water retention curve.

2.3. Incubation Experiment. Incubation experiments were conducted to evaluate the effects of biochar on soil properties. The studied soil $(15 \mathrm{~kg})$ was placed in plastic pots $(30 \mathrm{~cm}$ in width and $40 \mathrm{~cm}$ in length) and then well mixed with the biochar at application rates of $2.5 \%, 5 \%$, and $10 \%(\mathrm{w} / \mathrm{w})$. The mixed soils were wetted to the field water capacity (60\% water holding capacity) including the control soil. The incubated pots were placed in a room at $28^{\circ} \mathrm{C}$ and weighed every $5 \mathrm{~d}$ to maintain the field water capacity. All treatments were 
conducted in triplicate. The total incubation time was $168 \mathrm{~d}$, and the soils were analyzed at 3-week intervals to determine their chemical and physical properties.

2.4. Micromorphological Observations. After incubation, Kubiena boxes were employed in collecting undisturbed blocks of unamended and amended soil to create thin sections used for observing micromorphological features. After air-drying, vertically oriented thin sections measuring $2.5 \mathrm{~cm}$ $\times 5 \mathrm{~cm} \times 30 \mu \mathrm{m}$ were prepared by Spectrum Petrographics (Vancouver, WA, USA). The thin sections were used to observe soil structures under a polarized microscope (Leica DM EP, Wetzlar, Germany). The microscale structure of the biochar sample was identified using optical microscopy with reflected light and, subsequently, scanning electron microscopy (SEM) (Hitachi, S-3000N, Japan). A backscattered electron image representing the mean atomic abundance in a black-and-white image was observed from the surface of the samples coated with Au. The mineral phases of the sample were identified using SEM and energy-dispersive spectroscopy (EDS) (Horiba, EMAX-ENERGY EX-200, Japan), in which an acceleration voltage and beam current of $15 \mathrm{kV}$ and $180 \mathrm{pA}$, respectively, were applied in a $25 \mathrm{~Pa}$ vacuum with $\mathrm{Au}$ coating. The analyzed points were selected using backscattered electron images to avoid damaging the samples.

2.5. Soil Erosion Experiment. All treatments (the same treatments as with the incubation for analyses of soil physiochemical properties) were filled in a stainless steel cylinder $(20 \mathrm{~cm}$ in diameter and $10 \mathrm{~cm}$ in height) and well put in the end of the erosional channel $(20 \mathrm{~cm}$ in width and $90 \mathrm{~cm}$ in length). This set of the treated soils was also incubated for $168 \mathrm{~d}$ and then used for the erosion experiment by using rainfall simulator, which was with a height of $9.5 \mathrm{~m}$, average diameter of $2.5 \mathrm{~mm}$ for rain drops, and an average terminal velocity of $8.5 \mathrm{~m} \mathrm{~s}^{-1}$ for rain drops. All devices and processes were according to the American Standard Testing Materials D7101-08 standard method [48]. The erosion experiment simulated a rainfall intensity of $80 \mathrm{~mm} \mathrm{~h}^{-1}$ and a slope gradient of $20^{\circ}$, because the $80 \mathrm{~mm} \mathrm{~h}^{-1}$ was the average rainfall intensity during typhoon season in the study area, and the slope gradient of $20^{\circ}$ is the average slope gradient in this mudstone area.

2.6. Statistical Analysis. The rainfall experiments for all treatments were conducted in triplicate. The triplicate data were subjected to mean separation analysis by using a oneway ANOVA test with a significance level of $P=0.05$. The differences between mean values were identified using Duncan's test. Pearson correlation coefficients were calculated to determine how the soil properties were related.

\section{Results}

3.1. General Properties of the Soil and Biochar. Table 1 lists some physicochemical properties of the soil and the biochars. The soil was silt clay loam and was characterized by very high $\mathrm{pH}$ and relatively low soil organic carbon (SOC) contents.
TABLE 1: General properties of the studied soil and the biochar.

\begin{tabular}{lcc}
\hline Properties & Soil & Rice hull biochar \\
\hline Sand (\%) & $7.90 \pm 1.20^{\mathrm{a}}$ & $\mathrm{ND}$ \\
Silt $(\%)$ & $58.6 \pm 5.30$ & $\mathrm{ND}$ \\
$\mathrm{Clay}(\%)$ & $33.5 \pm 2.70$ & $\mathrm{ND}$ \\
$\mathrm{pH}$ & $8.70 \pm 0.05$ & $7.90 \pm 0.02$ \\
$\mathrm{SOC}(\%)$ & $0.49 \pm 0.05$ & $3.27 \pm 0.05$ \\
Total carbon $(\%)$ & $3.35 \pm 0.53$ & $33.0 \pm 0.61$ \\
Total nitrogen $(\%)$ & $0.06 \pm 0.02$ & $0.41 \pm 0.03$ \\
CaCO $\left(\mathrm{g}^{\prime} \mathrm{kg}^{2}\right.$ & $22.1 \pm 1.29$ & $4.56 \pm 0.53$ \\
$\mathrm{CEC}\left(\mathrm{cmol} \mathrm{kg}^{-1}\right)$ & $9.83 \pm 0.27$ & $26.0 \pm 1.13$ \\
$\mathrm{Ca}\left(\mathrm{cmol} \mathrm{kg}^{-1}\right)$ & $26.2 \pm 1.18$ & $2.44 \pm 0.18$ \\
$\mathrm{Na}\left(\mathrm{cmol} \mathrm{kg}^{-1}\right)$ & $1.58 \pm 0.07$ & $1.26 \pm 0.35$ \\
$\mathrm{Mg}\left(\mathrm{cmol} \mathrm{kg}^{-1}\right)$ & $0.63 \pm 0.03$ & $1.91 \pm 0.44$ \\
$\mathrm{~K}\left(\mathrm{cmol} \mathrm{kg}^{-1}\right)$ & $0.37 \pm 0.03$ & $18.7 \pm 0.30$ \\
$\mathrm{SSA}\left(\mathrm{m}^{2} \mathrm{~g}^{-1}\right)$ & $\mathrm{ND}$ & 15.1 \\
\hline
\end{tabular}

ND: not determined; SOC: soil organic carbon estimated by wet oxidation method; CEC: cation exchange capacity; $\mathrm{Ca}, \mathrm{Mg}, \mathrm{K}$, and $\mathrm{Na}$ were determined as the exchangeable forms; SSA: specific surface area.

${ }^{\text {a }}$ standard deviation.

Most of the total carbon was composed of calcite carbonate in the studied soil. Total nitrogen contents were also less than $0.10 \%$ in this soil. The CEC was around $10 \mathrm{cmole}(+) \mathrm{kg}^{-1}$, which corresponded to low amounts of SOC and clay fraction in the soil. Relatively high amounts of exchangeable $\mathrm{Ca}$ and $\mathrm{Na}$ were found in the soil, particularly in $\mathrm{Ca}$ (Table 1). Exchangeable $\mathrm{Mg}$ and $\mathrm{K}$ were less than $0.70 \mathrm{cmole}(+) \mathrm{kg}^{-1}$ in the soil.

The $\mathrm{pH}$ of the RHB-400 was 7.9. The contents of SOC, total $\mathrm{C}$, and total $\mathrm{N}$ in $\mathrm{RHB}-400$ were $3.27 \%, 33.0 \%$, and $0.41 \%$, respectively (Table 1 ). About $0.3 \%$ of $\mathrm{CaCO}_{3}$ was found in the RHB-400. The CEC of the RHB-400 $\left(26.0 \mathrm{cmol} \mathrm{kg}^{-1}\right)$ was higher than the soil. Table 1 further shows that exchangeable $\mathrm{Mg}$ and $\mathrm{K}$ were much higher in the biochars than in the studied soil. Specific surface area (SSA) was about $15.1 \mathrm{~m}^{2} \mathrm{~g}^{-1}$. Regarding functional groups in the biochar, the FTIR analysis of biochar revealed large proportions of $\mathrm{OH}$-stretching vibrations from the H-bonded hydroxyl $(\mathrm{O}-\mathrm{H})$ group $\left(3365 \mathrm{~cm}^{-1}\right)$ of phenol (aromatic compound) and carbonate (Figure 2).

3.2. Changes in Physical Properties after Biochar Application. Table 2 shows the physical properties of the biochar-amended soils after $168 \mathrm{~d}$ of incubation. The $\mathrm{Bd}$ of the amended soils significantly decreased from $1.59 \mathrm{Mg} \mathrm{m}^{-3}$ of the control to $1.40 \mathrm{Mg} \mathrm{m}^{-3}, 1.35 \mathrm{Mg} \mathrm{m}^{-3}$, and $1.19 \mathrm{Mg} \mathrm{m}^{-3}$ of the treatments with $2.5 \%, 5 \%$, and $10 \%$ of RHB- 400 , respectively. Besides, PR was also reduced from $14.5 \mathrm{~kg} \mathrm{~cm}^{-2}$ in the control sample to $1.2-6.3 \mathrm{~kg} \mathrm{~cm}^{-2}$ in the biochar-amended soils after $168 \mathrm{~d}$ incubation. In addition to obvious decreases in the $\mathrm{Bd}$ and PR, significantly higher total porosity was also found in the biochar-amended soils $(44.5 \%-46.7 \%)$ compared to the control (38.3\%), as well as the MWD of the soil aggregates, 
TABLE 2: Physical properties of the studied soil with different biochar treatments after 168 days.

\begin{tabular}{lccccc}
\hline Biochar & AR & $\begin{array}{c}\mathrm{Bd} \\
\mathrm{Mg} \mathrm{m}^{-3}\end{array}$ & $\begin{array}{c}\text { PR } \\
\mathrm{kg} \mathrm{cm}^{-2}\end{array}$ & $\begin{array}{c}\text { Porosity } \\
\%\end{array}$ & $\begin{array}{c}\text { MWD } \\
\mathrm{mm}\end{array}$ \\
\hline Control & $0 \%$ & $1.59 \pm 0.03^{\mathrm{e}}$ & $14.5 \pm 1.47^{\mathrm{i}}$ & $38.3 \pm 2.44^{\mathrm{a}}$ & $1.15 \pm 0.30^{\mathrm{ab}}$ \\
& $2.5 \%$ & $1.40 \pm 0.03^{\mathrm{a}}$ & $6.30 \pm 0.19^{\mathrm{h}}$ & $44.5 \pm 1.97^{\mathrm{ab}}$ & $1.74 \pm 0.28^{\mathrm{cde}}$ \\
RHB-400 & $5.0 \%$ & $1.35 \pm 0.01^{\mathrm{a}}$ & $2.20 \pm 0.16^{\mathrm{ef}}$ & $46.7 \pm 0.54^{\mathrm{bc}}$ & $1.77 \pm 0.35^{\mathrm{cde}}$ \\
& $10 \%$ & $1.19 \pm 0.06^{\mathrm{d}}$ & $1.20 \pm 0.13^{\mathrm{bc}}$ & $45.3 \pm 2.55^{\mathrm{bc}}$ & $2.09 \pm 0.17^{\mathrm{de}}$ \\
\hline
\end{tabular}

Values followed by the same letter within a column are not significantly different at $P<0.05$ level based on Duncan's test.

AR: application rate; Bd: bulk density; PR: penetration resistance; MWD: mean weight diameter of soil aggregates.

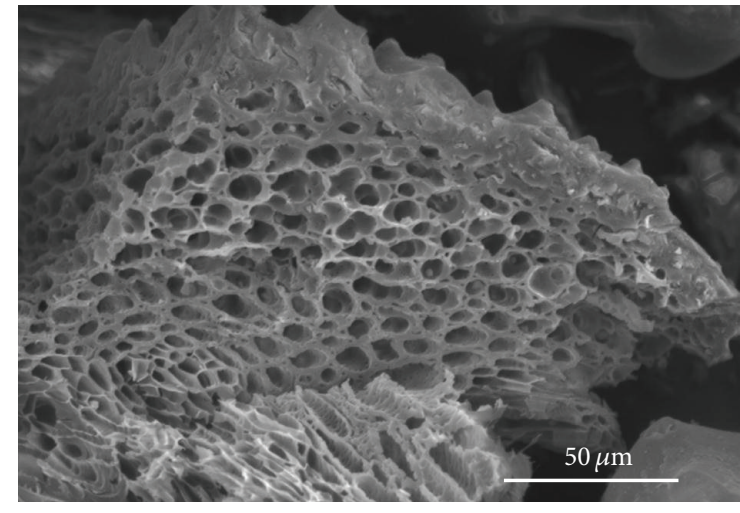

(a)

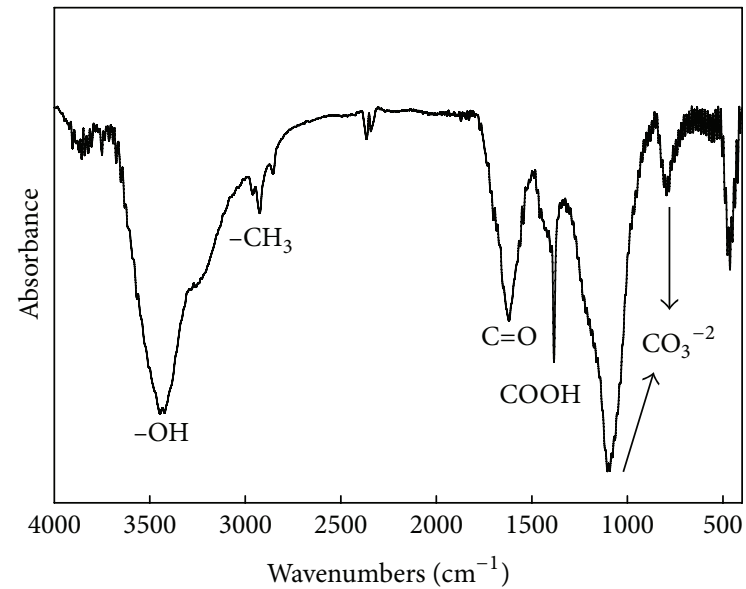

(b)

FIGURE 2: Scanning electron microscope (SEM) images (a) and Fourier-transform infrared (IR) spectrums of the rice hull biochar (RHB-400) (b).

which increased from $1.15 \mathrm{~mm}$ to $1.74 \mathrm{~mm}-2.09 \mathrm{~mm}$ after biochar application.

\subsection{Changes of Hydraulic Properties and Soil Loss Contents} after Biochar Application. The biochars incorporation significantly increased water holding capacity (WHC) after $168 \mathrm{~d}$ incubation, particularly in the volumetric water contents $\left(\theta_{v}\right)$ at low matric potentials (Figure 3). After incubation, the $\theta_{v}$ increased by $16 \%$ to $62 \%$ at -0.3 bar (field water capacity (FWC) and by $16 \%$ to $52 \%$ at -15 bar (wilting point (WP)) in the biochar treatments (Table 2). Meanwhile, the available water content (AWC) also increased considerably by $18 \%$ to $89 \%$ in the biochar treatments. The highest contents of FWC, WP, and AWC were always found at 10\% biocharamended soils. As shown in Table 3 and Figure 3, macropore proportion $(\%)$ significantly $(P<0.05)$ increased after incorporation of biochars from $6.14 \%$ in the control to $6.44 \%-$ $7.79 \%$ in the amended soils, particularly in $10 \%$ biochar treatment. Table 3 also shows that the $K_{\text {sat }}$ was determined only in the $10 \%$ biochar-amended soils after incubation. This indicated that a high biochar application rate $(\geq 10 \%)$ improved the water conductivity of the soil. Soil loss contents at a simulated rainfall intensity of $80 \mathrm{~mm} \mathrm{~h}^{-1}$ and at a slope gradient of $20^{\circ}$ are also presented in Table 3 . The highest soil loss contents occurred in the control, and the lowest soil loss contents occurred in the amended soils with $10 \%$ biochar.
The soil loss contents significantly decreased with increasing biochar application rate.

\section{Discussion}

4.1. Improvement of the Physical Properties of the Studied Soils. In this study, biochar incorporation obviously improved soil physical properties, particularly in soil strength and soil structure. Soil strength was commonly reflected by $\mathrm{Bd}$ and PR. The Bd of biochar-amended soils significantly decreased by $12 \%$ to $25 \%$ compared with the control. This was especially true for the 10\% biochar treatment (Table 2). For agronomic aspect, high $\mathrm{Bd}\left(\sim 1.60 \mathrm{~g} \mathrm{~cm}^{-3}\right)$ of the control might restrict root extensibility and therefore inhibit growth of crops [9]. The $\mathrm{Bd}$ in the biochar-amended soils $\left(<1.4 \mathrm{~g} \mathrm{~cm}^{-3}\right)$ has been accepted for tillage and crop growth (Table 2) [49]. Furthermore, $2.5 \%$ biochar incorporation was recommended in this study, because PR might be much suitable for plant growth in this treatment $\left(2.0-6.0 \mathrm{~kg} \mathrm{~cm}^{-2}\right)$ which was proposed by [49]

Soil structure was always determined by porosity and soil aggregates. In the present study, porosity and aggregate size were increased after the biochar application (Table 2). The obvious change of porosity in this study was considered as the formation of macropores and rearrangement of soil particles. Based on the study, macropores ( $>75 \mu \mathrm{m}$ in diameter) 
TABLE 3: Mean soil volumetric moisture contents measured at different matric potentials, macropores, and saturated water conductivity of the control and biochar-amended soils after incubation $(n=3)$.

\begin{tabular}{lccccccrc}
\hline Biochar & AR & Macropore & Micropore & FWC & WP & AWC & $\begin{array}{c}K_{\text {sat }} \\
\text { cm day }^{-1}\end{array}$ \\
\hline Control & $0 \%$ & $6.14 \pm 0.14^{\mathrm{a}}$ & $29.3 \pm 0.42^{\mathrm{a}}$ & $22.7 \pm 1.17^{\mathrm{a}}$ & $16.3 \pm 0.68^{\mathrm{a}}$ & $6.41 \pm 0.25^{\mathrm{a}}$ & $\mathrm{NA}^{\mathrm{S}}$ & $580 \pm 110^{\mathrm{a}}$ \\
& $2.5 \%$ & $6.44 \pm 0.12^{\mathrm{b}}$ & $32.8 \pm 0.28^{\mathrm{b}}$ & $26.5 \pm 1.08^{\mathrm{b}}$ & $18.9 \pm 0.52^{\mathrm{b}}$ & $7.54 \pm 0.50^{\mathrm{b}}$ & NA & $378 \pm 36.8^{\mathrm{b}}$ \\
\multirow{2}{*}{ RHB-400 } & $5.0 \%$ & $6.38 \pm 0.22^{\mathrm{b}}$ & $35.4 \pm 2.71^{\mathrm{c}}$ & $29.6 \pm 1.45^{\mathrm{bc}}$ & $19.8 \pm 0.88^{\mathrm{b}}$ & $9.74 \pm 1.78^{\mathrm{b}}$ & $\mathrm{NA}$ & $120 \pm 52.6^{\mathrm{c}}$ \\
& $10 \%$ & $7.79 \pm 1.15^{\mathrm{c}}$ & $45.4 \pm 2.99^{\mathrm{d}}$ & $36.9 \pm 2.60^{\mathrm{d}}$ & $24.8 \pm 0.42^{\mathrm{c}}$ & $12.1 \pm 0.18^{\mathrm{c}}$ & $2.17 \pm 2.03$ & $60.2 \pm 43.0^{\mathrm{c}}$ \\
\hline
\end{tabular}

AR: application rate; FWC: field water content; WP: wilting point; AWC: available water content; $K_{\text {sat }}$ s saturated hydraulic conductivity; SLC: soil loss contents. Values followed by the same letter within a column are not significantly different at $P<0.05$ level based on Duncan's test. NA: not available.

TABLE 4: Soil organic carbon contents and microbial biomass carbon of the studied soils after $168 \mathrm{~d}$ incubation.

\begin{tabular}{lccc}
\hline Treatments & Application rate & $\begin{array}{c}\text { Organic carbon contents } \\
\mathrm{g} \mathrm{kg}^{*}\end{array}$ & $\begin{array}{c}\text { Microbial biomass carbon } \\
\mathrm{mg} \mathrm{kg}^{-1}\end{array}$ \\
\hline Control & $0 \%$ & $0.68 \pm 0.05^{\mathrm{a}}$ & $31.3 \pm 1.18^{\mathrm{a}}$ \\
& $2.5 \%$ & $1.51 \pm 0.08^{\mathrm{b}}$ & $33.7 \pm 2.08^{\mathrm{a}}$ \\
RHB-400 & $5.0 \%$ & $2.08 \pm 0.03^{\mathrm{c}}$ & $53.8 \pm 25.2^{\mathrm{ab}}$ \\
& $10 \%$ & $3.71 \pm 0.10^{\mathrm{d}}$ & $129 \pm 26.3^{\mathrm{c}}$ \\
\hline
\end{tabular}

* Organic carbon contents were determined by differences between contents of total carbon and carbon derived from $\mathrm{CaCO}_{3}$. Different letters beside the values mean significant difference $(P<0.05)$ at the same column.

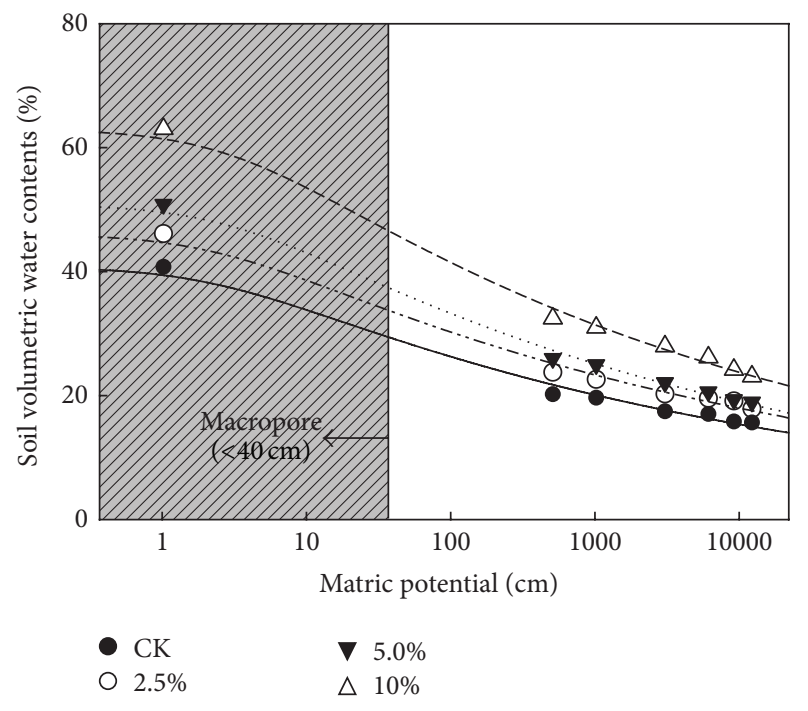

FIGURE 3: Water retention curves for the mudstones amended with rice hull biochars (RHB-400) after $168 \mathrm{~d}$ of incubation.

increased obviously after biochar incorporation (Table 3 ), and this might be attributed to the dilution effect [12] and soil particle rearrangement [10]. As shown in Table 3 and Figure 3 , macropores obviously increased by $4 \%$ to $27 \%$ in the biochar-amended soils after incubation. This finding was similar to the result of Lei and Zhang [50] who indicated 5\%$35 \%$ increases of macropore proportion in sandy loam soil after application of $5 \%$ wood biochar. They also proposed that change of porosity in biochar-amended soils resulted from the rearrangement of soil particles. Meanwhile, micropores were also obviously increased after incorporation of biochar
(Figure 3, Table 3). Numerous micropores in the biochar itself observed in Figure 2(a) might be responsible for a large increase of micropores in the biochar-amended soils $[12,13]$.

Except for obvious increases of macro- and micropores in the amended soils, rearrangement of soil particles also obviously coarsens soil aggregates in this study, particularly in the $10 \%$ biochar treatment (Table 3). Regarding increases of MWD of soil aggregate after biochar application in this study, the increases in the TOC contents and microbial activity might be the critical reasons, which also agreed with $[10,23]$. The present study revealed that the TOC content increased from $0.7 \%$ to $1.5-3.7 \%$ in the biochar-amended soils, and the MBC content also increased, especially with the $10 \%$ biochar treatments (Table 4 ). The formation of soil aggregates might result from the interaction between the surface of soil particles and functional groups (e.g., phenolic and carboxylic groups (Figure 2)) contained in the biochar [12]. Observations of the microstructures in the biocharamended soils indicated that soil particles (clay) seemed to be adsorbed on the biochar, forming microaggregates (Figures 4(a) and 4(b)) and then continuing to combine with other soil-biochar complexes to form new macroaggregates (Figure 4(c)). Jien and Wang [10] also observed a similar process when they incorporated a wood biochar into the highly weathered soil.

4.2. Improvement of Hydraulic Characteristics by Biochar Application. Poor WHC implicated insufficiently available water in soils for plant growing. In this study, the poor WHC of the mudstone soil was attributed to less organic substance contents and poor soil structure. Not only increase of organic substances, but also improvement of soil structure was found after biochar incorporation into the soil. The FWC, 


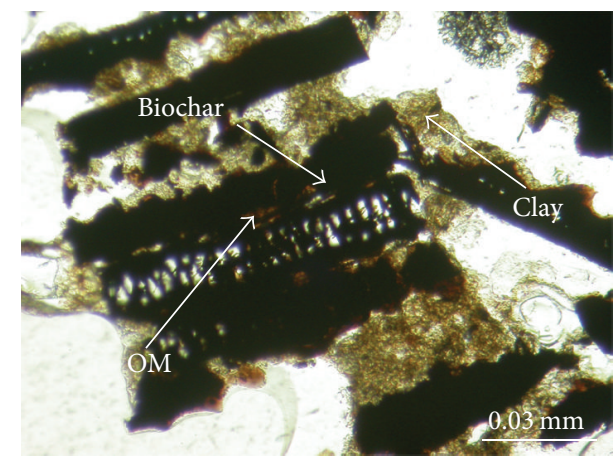

(a)

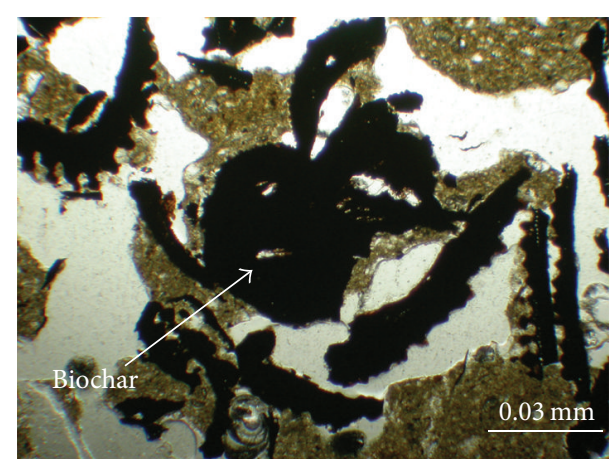

(b)

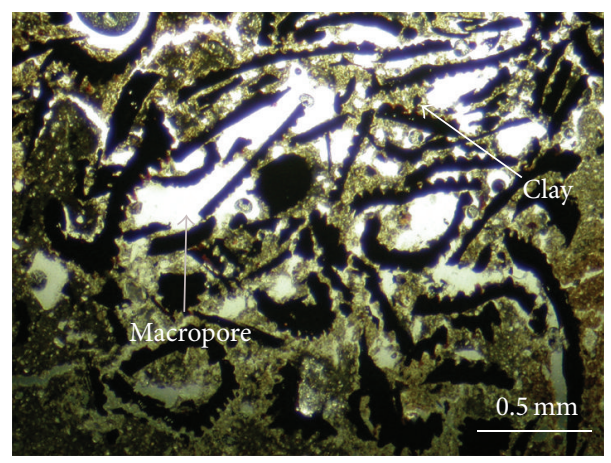

(c)

FIGURE 4: Micrographs of thin sections of soils amended with biochar: (a) soil aggregates with 5\% application rate of RHB-400 with plain polarized light (PPL); (b) soil aggregates with 5\% application rate of RHB-700 with plain polarized light (PPL); (c) soil aggregates with 10\% application rate of RHB-700 with plain polarized light (PPL).

WP, and AWC also significantly increased by $60 \%, 44 \%$, and $104 \%$, respectively, in the amended soils as compared with the control after incubation (Table 3, Figure 3). This further implicated that plants could obtain much water in this mudstone area where there is always water deficiency during growing season. Lei and Zhang [50] indicated that biochar application directly increased the WHC through the inner surface area of the biochar and indirectly increased the WHC by facilitating the formation of soil aggregates and macropores.

In this study, Figure 3 shows that $\theta_{v}$ in the biocharamended soils was higher than in the control at any matric potential throughout the incubation period. This further implicated that macropores and micropores obviously increased after biochar application. The micromorphological observations in our study also indicated the rearrangement of soil particles in the biochar-amended soils (Figure 4). The increase of WHC at higher matric potentials can be ascribed to the extremely high inner SSAs of the biochar and the textural pores produced by the formation of aggregates (complexes of the biochar and soil particles) (Figures 4(a) and 4(b)). Rawls et al. [51] indicated that soil water retention was strongly influenced by organic matter at -0.3 to -15 bar. Liu et al. [52] stated that the WHC was determined by organic matter content and intraaggregate pores at matric potentials of 0.1 and 5 bar. Our results corresponded with the findings of Liu et al. [52], who determined that larger aggregates retained more water than smaller aggregates at matric potentials of 0.1 and 5 bar because of intraaggregate pores. Kutílek et al. [53] indicated that water retention at lower matric potential depends on the contents of larger pores, which is strongly influenced by soil structure, while water retention at higher matric potentials is affected more by soil texture and surface area. The formation of a larger inner surface area and the more porous structure of the RHB produced by a higher temperature could be the main reason why the RHB-700 treatments retained more water than the RHB-400 treatments did; this explanation was consistent with those of Verheijen et al. [54] and Lei and Zhang [50].

In addition, the $K_{\text {sat }}$ increased in the $10 \%$ biocharamended soil. The $K_{\text {sat }}$ results followed a trend similar to that of the macropore results in the biochar-amended treatments. The large increase in $K_{\text {sat }}$ in the $10 \%$ biochar-amended soils may be attributed to the increase in macropores ( $>$ -0.04 bar), which was observed at low matric potentials (Figure 3). Macropores might be formed through dilution effects and the rearrangement of soil particles when the surfaces of clay and biochar interact [10]; this process was evidenced in our micromorphological observations (Figure 4). Herath et al. [12] proved that the $K_{\text {sat }}$ was determined by the macropore proportions, particularly in poorly drained soils. Lei and Zhang [50] also indicated that $K_{\text {sat }}$ increased after woodchip and dairy manure biochar was added because of the improvements in soil aggregation and macropores. 
TABle 5: Pearson's correlation coefficients among soil properties at the end of incubation time (after $168 \mathrm{~d}$ ), $n=12$.

\begin{tabular}{|c|c|c|c|c|c|c|c|c|}
\hline & $\mathrm{Bd}$ & $\mathrm{PR}$ & Porosity & MWD & $\mathrm{MaP}$ & $\mathrm{MiP}$ & AWC & SLC \\
\hline $\mathrm{Bd}$ & 1.00 & & & & & & & \\
\hline PR & $0.90^{* *}$ & 1.00 & & & & & & \\
\hline Porosity & $-0.73^{* *}$ & $-0.69^{*}$ & 1.00 & & & & & \\
\hline MWD & $-0.87^{* *}$ & $-0.65^{*}$ & $0.68^{*}$ & 1.00 & & & & \\
\hline $\mathrm{MaP}$ & $-0.95^{* *}$ & $-0.88^{* *}$ & $0.79^{* *}$ & $0.80^{* *}$ & 1.00 & & & \\
\hline MiP & $-0.94^{* *}$ & $-0.84^{* *}$ & $0.66^{* *}$ & $0.82^{* *}$ & $0.97^{* *}$ & 1.00 & & \\
\hline AWC & $-0.95^{* *}$ & $-0.84^{* *}$ & $0.72^{* *}$ & $0.83^{* *}$ & $0.97^{* *}$ & $0.95^{* *}$ & 1.00 & \\
\hline SLC & $0.91^{* *}$ & $0.93^{* *}$ & $-0.72^{* *}$ & $-0.80^{* *}$ & $-0.85^{* *}$ & $-0.82^{* *}$ & $-0.88^{* *}$ & 1.00 \\
\hline
\end{tabular}

${ }^{*} P<0.05 ;{ }^{* *} P<0.01$.

Bd: bulk density; PR: penetration resistance; MWD: mean weight diameter of soil aggregates; MaP: macropores; MiP: micropores; AWC: available water content; SLC: soil loss contents.

4.3. Improvement of Soil Erosion Potential by Biochar Application in Mudstone Soil. From the result of correlation analysis, significantly positive correlations were presented between $\mathrm{Bd}$ and soil loss contents $(r=0.91, P<0.01)$ and between PR and soil loss contents $(r=0.93, P<0.01)$ (Table 5). Reduction of soil strength might be the major factor in decreasing of the soil loss contents in the biochar-amended soil. Soil crusting can increase $\mathrm{Bd}$ and $\mathrm{PR}$ and therefore increased the runoff and sediment yields [55]. Singer and Shainberg [56] also explained that the formation of crusting and sealing increases the erosion rate and sediment yield on slopelands. In this study, the dilution effect and the formation of microaggregates or macroaggregates induced by biochar incorporation might be the key factors to reduce crusting. Reduction of soil crusting therefore increased infiltration ability, followed by the decreasing of soil loss contents (Table 3).

Except for reduction of soil strength in the amended soils, the change of soil structure including increase of porosity and aggregate stability could be identified as a minor factor to reduce soil loss contents in the studied soil. Soil aggregation stability is generally considered to be related to the erosion of degraded soils [31, 52]. An et al. [57] indicated that the content of stable aggregates most strongly reflected the ability of soil to resist erosion on the Loess Plateau. In this study, porosity $(r=-0.72, P<0.01)$, soil aggregate size $(r=-0.80$, $P<0.01)$, macropores $(r=-0.85, P<0.01)$, and micropores $(r=-0.82, P<0.01)$ were significantly negatively correlated to soil loss contents (Table 5). Redistribution of soil particles by applying biochar increased the soil aggregate stability to prevent the soil particles from detaching and increased the number of macropores, facilitating the permeability of the soil. Liu et al. [52] indicated that applying biochar may reduce soil erosion by improving the aggregate stability of soil; these results corresponded with our results. The unamended mudstone soils were highly susceptible to water erosion because of their unstable aggregates. Approximately $80 \%$ of the soil aggregates in the unamended mudstone soils examined in this study exhibited diameters that were less than $0.05 \mathrm{~mm}$, indicating that the aggregates in the hardsetting mudstone soils were unstable. This result corresponded with the description by Le Bissonnais [41], who indicated that soils were considered highly unstable when their MWDs were $<0.4 \mathrm{~mm}$. Cantón et al. [58] stated that aggregate stability and macroaggregate formation were crucial for maintaining soil porosity and improving soil erosion. Barthès and Roose [59] reported that soil losses were negatively correlated with stable macroaggregate $(>0.2 \mathrm{~mm})$ contents $(r=0.99, P<0.01)$ in topsoils at a certain simulated rainfall intensity $\left(60 \mathrm{~mm} \mathrm{~h}^{-1}\right)$.

\section{Conclusion}

Agronomy and engineering solutions, including tillage, forest restoration, soil erosion prevention, tunneling, and road construction in mudstone areas, are worldwide problems, because of the poor physical properties of these soils. Our results indicated that applying rice hull biochar can effectively improve poor soil physiochemical properties and reduce the soil erosion potential in mudstone areas. Our results further indicated that biochar incorporation could significantly reduce soil strength by decreasing the $\mathrm{Bd}$ and the PR after a short-term incubation. Moreover, soil structure could also be changed by increasing porosity, aggregate size, and FWC from $6 \%$ to $18 \%, 0.3$ to $1.05 \mathrm{~mm}$, and $3.8 \%$ to $17 \%$, respectively. Meanwhile, biochar application could be expected to significantly reduce soil loss contents by $35 \%$ to $90 \%$ under an extreme rainfall event based on the results.

\section{Conflict of Interests}

The authors declare that there is no conflict of interests regarding the publication of this paper.

\section{Acknowledgments}

The authors would like to thank the National Science Council of Taiwan, Taiwan, for financially supporting this research under Contract no. NSC-101-2313-B-020-013-MY2. The authors are also grateful to Dr. Chuan-Chi Chien from the Industrial Technology Research Institute in Tainan, Taiwan, for providing the rice hull biochar. 


\section{References}

[1] M. Leh, S. Bajwa, and I. Chaubey, "IMPACT of land use change on erosion risk: an integrated remote sensing, geographic information system and modeling methodology," Land Degradation and Development, vol. 24, no. 5, pp. 409-421, 2013.

[2] M. Qadir, A. D. Noble, and C. Chartres, "Adapting to climate change by improving water productivity of soils in dry areas," Land Degradation and Development, vol. 24, no. 1, pp. 12-21, 2013.

[3] D. Mandal and V. N. Sharda, "Appraisal of soil erosion risk in the eastern himalayan region of india for soil conservation planning," Land Degradation and Development, vol. 24, no. 5, pp. 430-437, 2013.

[4] F. M. Ziadat and A. Y. Taimeh, "Effect of rainfall intensity, slope, land use and antecedent soil moisture on soil erosion in an arid environment," Land Degradation and Development, vol. 24, no. 6, pp. 582-590, 2013.

[5] K. Y. Chan, L. Van Zwieten, I. Meszaros, A. Downie, and S. Joseph, "Agronomic values of greenwaste biochar as a soil amendment," Australian Journal of Soil Research, vol. 45, no. 8, pp. 629-634, 2007.

[6] K. Y. Chan, L. van Zwieten, I. Meszaros, A. Downie, and S. Joseph, "Using poultry litter biochars as soil amendments," Australian Journal of Soil Research, vol. 46, no. 5, pp. 437-444, 2008.

[7] J. L. Deenik, A. Diarra, G. Uehara, S. Campbell, Y. Sumiyoshi, and M. J. Antal Jr., "Charcoal ash and volatile matter effects on soil properties and plant growth in an acid ultisol," Soil Science, vol. 176, no. 7, pp. 336-345, 2011.

[8] L. van Zwieten, S. Kimber, S. Morris et al., "Effects of biochar from slow pyrolysis of papermill waste on agronomic performance and soil fertility," Plant and Soil, vol. 327, no. 1, pp. 235246, 2010.

[9] C. J. Atkinson, J. D. Fitzgerald, and N. A. Hipps, "Potential mechanisms for achieving agricultural benefits from biochar application to temperate soils: a review," Plant and Soil, vol. 337, no. 1, pp. 1-18, 2010.

[10] S.-H. Jien and C.-S. Wang, "Effects of biochar on soil properties and erosion potential in a highly weathered soil," Catena, vol. 110, pp. 225-233, 2013.

[11] J. M. Kimetu and J. Lehmann, "Stability and stabilisation of biochar and green manure in soil with different organic carbon contents," Australian Journal of Soil Research, vol. 48, no. 6-7, pp. 577-585, 2010.

[12] H. M. S. K. Herath, M. Camps-Arbestain, and M. Hedley, "Effect of biochar on soil physical properties in two contrasting soils: an Alfisol and an Andisol," Geoderma, vol. 209-210, pp. 188-197, 2013.

[13] D. Dimoyiannis, "Wet aggregate stability as affected by excess carbonate and other soil properties," Land Degradation and Development, vol. 23, no. 5, pp. 450-455, 2012.

[14] R. Kocyigit and S. Demirci, "Long-term changes of aggregateassociated and labile soil organic carbon and nitrogen after conversion from forest to grassland and cropland in northern Turkey," Land Degradation and Development, vol. 23, no. 5, pp. 475-482, 2012.

[15] A. Cerdà, "Aggregate stability against water forces under different climates on agriculture land and scrubland in southern Bolivia," Soil and Tillage Research, vol. 57, no. 3, pp. 159-166, 2000.
[16] B. Liang, J. Lehmann, D. Solomon et al., "Black carbon increases cation exchange capacity in soils," Soil Science Society of America Journal, vol. 70, no. 5, pp. 1719-1730, 2006.

[17] C. Steiner, N. Melear, K. Harris, and K. Das, "Biochar as bulking agent for poultry litter composting," Carbon Management, vol. 2, no. 3, pp. 227-230, 2011.

[18] D. A. Laird, P. Fleming, D. D. Davis, R. Horton, B. Wang, and D. L. Karlen, "Impact of biochar amendments on the quality of a typical Midwestern agricultural soil," Geoderma, vol. 158, no. 3-4, pp. 443-449, 2010.

[19] J.-H. Yuan and R.-K. Xu, "The amelioration effects of low temperature biochar generated from nine crop residues on an acidic Ultisol," Soil Use and Management, vol. 27, no. 1, pp. 110115, 2011.

[20] P. M. Trompowsky, V. De Melo Benites, B. E. Madari, A. S. Pimenta, W. C. Hockaday, and P. G. Hatcher, "Characterization of humic like substances obtained by chemical oxidation of eucalyptus charcoal," Organic Geochemistry, vol. 36, no. 11, pp. 1480-1489, 2005.

[21] M. Tejada and J. L. Gonzalez, "Influence of organic amendments on soil structure and soil loss under simulated rain," Soil and Tillage Research, vol. 93, no. 1, pp. 197-205, 2007.

[22] M. N. Wuddivira, R. J. Stone, and E. I. Ekwue, "Structural stability of humid tropical soils as influenced by manure incorporation and incubation duration," Soil Science Society of America Journal, vol. 73, no. 4, pp. 1353-1360, 2009.

[23] S. A. Materechera, "Aggregation in a surface layer of a hardsetting and crusting soil as influenced by the application of amendments and grass mulch in a South African semi-arid environment," Soil and Tillage Research, vol. 105, no. 2, pp. 251259, 2009.

[24] K. Jindo, K. Matsumoto, C. García Izquierdo, T. Sonoki, and M. A. Sanchez-Monedero, "Methodological interference of biochar in the determination of extracellular enzyme activities in composting samples," Soil Earth, vol. 5, pp. 713-719, 2014.

[25] A. Mukherjee, R. Lal, and A. R. Zimmerman, "Effects of biochar and other amendments on the physical properties and greenhouse gas emissions of an artificially degraded soil," Science of the Total Environment, vol. 487, no. 1, pp. 26-36, 2014.

[26] T. A. Ghezzehei, D. V. Sarkhot, and A. A. Berhe, "Biochar can be used to capture essential nutrients from dairy wastewater and improve soil physico-chemical properties," Soil Earth, vol. 5, pp. 953-962, 2014.

[27] R. Lal, Soil Erosion in the Tropics: Principles and Management, McGraw-Hill, New York, NY, USA, 1990.

[28] C. E. Mullins, P. S. Blackwell, and J. M. Tisdall, "Strength development during drying of a cultivated, flood-irrigated hardsetting soil. I. Comparison with a structurally stable soil," Soil and Tillage Research, vol. 25, no. 2-3, pp. 113-128, 1992.

[29] D. H. Lee, Y. Y. Jhin, and K. G. Tien, "Characteristics of mudstone and the methods for slope protection," Sino-Geotechnics, vol. 48, pp. 35-47, 1994.

[30] S. Z. Chen, "A study on the erosion characteristics of the mudstone in the southwestern Taiwan," Tech. Rep. 74-5, Disaster Prevention Investigation, National Science Council, Taipei, Taiwan, 1984.

[31] W. J. Busscher, J. M. Novak, and M. Ahmedna, "Physical effects of organic matter amendment of a southeastern US coastal loamy sand," Soil Science, vol. 176, no. 12, pp. 661-667, 2011.

[32] P. Hueso-González, J. F. Martinez-Murillo, and J. D. RuizSinoga, "The impact of organic amendments on forest soil 
properties under Mediterranean climatic conditions," Land Degradation \& Development, 2014.

[33] Soil Survey Staff, Keys to Soil Taxonomy, USDA-NRCS, Agricultural Handbook no. 436, U.S. Government Printing Office, Washington, DC, USA, 11th edition, 2010.

[34] G. W. Gee and J. W. Bauder, "Particle-size analysis," in Methods of Soil Analysis, A. Klute, Ed., vol. 9 of Agronomy Monograph, pp. 383-411, ASA and SSSA, Madison, Wisc, USA, 1986.

[35] E. O. McLean, "Soil pH and lime requirement," in Methods of Soil Analysis: Part 2. Chemical and Microbiological Methods, A. L. Page, Ed., Agronomy Monograph 9, pp. 199-224, America Society of Agronomy and Soil Science Society of America, Madison, Wis, USA, 2nd edition, 1982.

[36] D. W. Nelson and L. E. Sommers, "Total carbon, organic carbon, and organic matter," in Methods of Soil Analysis: Part 2. Chemical and Microbiological Methods, A. L. Page and A. Klute, Eds., Agronomy Monograph 9, pp. 539-579, America Society of Agronomy and Soil Science Society of America, Madison, Wis, USA, 2nd edition, 1982.

[37] G. W. Thomas, "Exchangeable cation," in Methods of Soil Analysis: Part 2. Chemical and Microbiological Methods, A. L. Page, R. H. Miller, and D. R. Keeney, Eds., Agronomy Monograph 9, pp. 159-165, America Society of Agronomy and Soil Science Society of America, Madison, Wis, USA, 2nd edition, 1982.

[38] R. H. Loeppert and D. L. Suarez, "Carbonate and gypsum," in Methods of Soil Analysis: Part 2. Chemical and Microbiological Methods, A. L. Page, D. R. Miller, and D. R. Keeney, Eds., Agronomy Monograph 9, pp. 437-451, America Society of Agronomy and Soil Science Society of America, Madison, Wis, USA, 2nd edition, 1982.

[39] G. R. Blake and K. H. Hartge, "Bulk density," in Methods of Soil Analysis. Part 1, A. Klute, Ed., Agronomy Monograph 9, pp. 383411, Soil Science Society of America, Madison, Wis, USA, 2nd edition, 1986.

[40] A. Klute and C. DirKsen, "Hydraulic conductivity and diffusivity: laboratory methods," in Methods of Soil Analysis. Part 1, A. Klute, Ed., Agronomy Monograph no. 9, pp. 687-734, Soil Science Society of America, Madison, Wis, USA, 1986.

[41] Y. Le Bissonnais, "Aggregate stability and assessment of soil crustability and erodibility: I. Theory and methodology," European Journal of Soil Science, vol. 47, no. 4, pp. 425-437, 1996.

[42] S. Brunauer, P. H. Emmett, and E. Teller, "Adsorption of gases in multimolecular layers," Journal of the American Chemical Society, vol. 60, no. 2, pp. 309-319, 1938.

[43] P. C. Brookes, A. Landman, G. Pruden, and D. S. Jenkinson, "Chloroform fumigation and the release of soil nitrogen: a rapid direct extraction method to measure microbial biomass nitrogen in soil," Soil Biology and Biochemistry, vol. 17, no. 6, pp. 837-842, 1985.

[44] E. D. Vance, P. C. Brookes, and D. S. Jenkinson, "An extraction method for measuring soil microbial biomass C," Soil Biology and Biochemistry, vol. 19, no. 6, pp. 703-707, 1987.

[45] Y. Chun, G. Sheng, and C. T. Chiou, "Evaluation of current techniques for isolation of chars as natural adsorbents," Environmental Science and Technology, vol. 38, no. 15, pp. 4227-4232, 2004.

[46] M. T. van Genuchten, "A closed form equation for predicting the hydraulic conductivity of unsaturated soils," Soil Science Society of America Journal, vol. 44, no. 5, pp. 892-898, 1980.

[47] R. Brewer, Fabric and Mineral Analysis of Soils, John Wiley \& Sons, New York, NY, USA, 1964.
[48] American Society of Testing and Materials (ASTM), "Standard Index Test Method for Determination of Unvegetated Rolled Erosion Control Product (RECP) Ability to Protect Soil from Rain Splash and Associated Runoff Under Bench-Scale Conditions," Annual Book of ASTM Standards D7101-08, 2008.

[49] I. Hakansson and J. Lipiec, "A review of the usefulness of relative bulk density values in studies of soil structure and compaction," Soil \& Tillage Research, vol. 53, no. 2, pp. 71-85, 2000.

[50] O. Lei and R. Zhang, "Effects of biochars derived from different feedstocks and pyrolysis temperatures on soil physical and hydraulic properties," Journal of Soils and Sediments, vol. 13, no. 9, pp. 1561-1572, 2013.

[51] W. J. Rawls, Y. A. Pachepsky, J. C. Ritchie, T. M. Sobecki, and H. Bloodworth, "Effect of soil organic carbon on soil water retention," Geoderma, vol. 116, no. 1-2, pp. 61-76, 2003.

[52] X. H. Liu, F. P. Han, and X. C. Zhang, "Effect of biochar on soil aggregates in the Loess Plateau: results from incubation experiments," International Journal of Agriculture and Biology, vol. 14, no. 6, pp. 975-979, 2012.

[53] M. Kutílek, L. Jendele, and K. P. Panayiotopoulos, “The influence of uniaxial compression upon pore size distribution in bimodal soils," Soil and Tillage Research, vol. 86, no. 1, pp. 27-37, 2006.

[54] F. Verheijen, S. Jeffery, A. C. Bastos, M. van der Velde, and I. Diafas, "Biochar application to soils. A critical scientific review of effects on soil properties, processes and functions," Office for the Official Publications of the European Communities, Luxemburg, 2009.

[55] L. Edwards, J. R. Burney, G. Richter, and A. H. MacRae, "Evaluation of compost and straw mulching on soil-loss characteristics in erosion plots of potatoes in Prince Edward Island, Canada," Agriculture, Ecosystems and Environment, vol. 81, no. 3, pp. 217222, 2000.

[56] M. J. Singer and I. Shainberg, "Mineral soil surface crusts and wind and water erosion," Earth Surface Processes and Landforms, vol. 29, no. 9, pp. 1065-1075, 2004.

[57] S.-S. An, Y.-M. Huang, F.-L. Zheng, and J.-G. Yang, "Aggregate characteristics during natural revegetation on the loess plateau," Pedosphere, vol. 18, no. 6, pp. 809-816, 2008.

[58] Y. Cantón, A. Solé-Benet, C. Asensio, S. Chamizo, and J. Puigdefábregas, "Aggregate stability in range sandy loam soils relationships with runoff and erosion," Catena, vol. 77, no. 3, pp. 192-199, 2009.

[59] B. Barthès and E. Roose, "Aggregate stability as an indicator of soil susceptibility to runoff and erosion; validation at several levels," Catena, vol. 47, no. 2, pp. 133-149, 2002. 

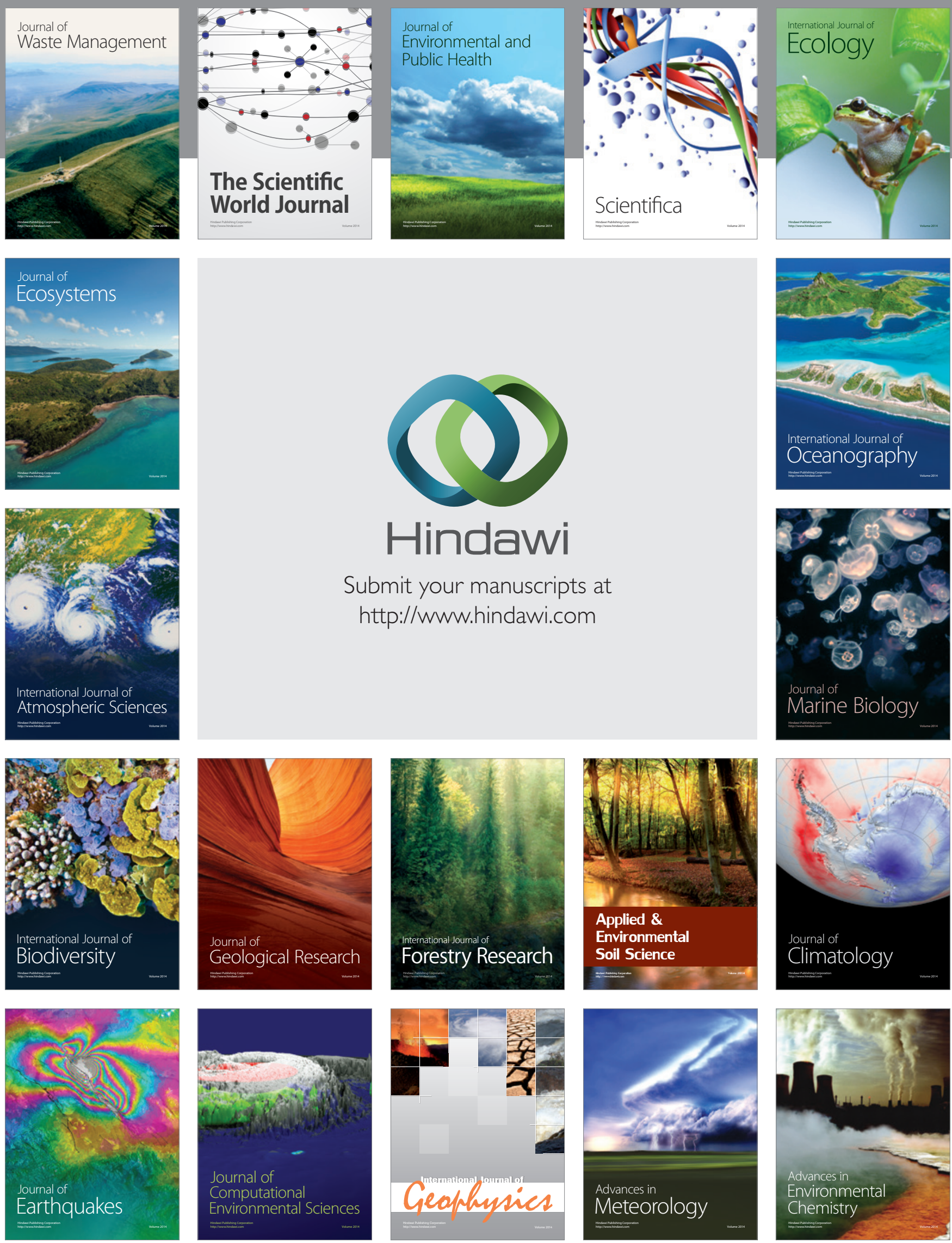